\title{
ORIGINALITY AND FUNCTION OF FORMAL STRUCTURES IN THE CHRONICLE OF MICHAEL THE GREAT
}

\author{
DOROTHEA WELTECKE \\ FAKULTÄT FÜR GESCHICHTE UND PHILOSOPHIE \\ ABTEILUNG GESCHICHTE \\ UNIVERSITÄT BIELEFELD
}

\begin{abstract}
The world chronicle or the universal chronography by Michael the Great is the most voluminous historical work written within the Syriac Orthodox tradition. Usually its content is used to gain historical data, either about events it is dealing with or about its sources. In the present paper some suggestions are made to read the work as a historical achievement in its own right.

Though very different from each other, both modern and post-modern thinking often evaluate historiography - at least historiography written by others — with categories developed for poetic literature. One of the consequences of this approach was and is a rather critical attitude towards the world historical achievement of the patriarch, which does not consist of a narrative in the strict sense of the term. While reserve and distance are useful elementsof sober historical analysis it should not exclude detachment from one's own point of view: History of historiography should be questioning both, the source and the self.
\end{abstract}


Ancient and medieval chronography is not directly linked to ancient and medieval narrative historiography, it served different functions, and it was not a "premature" stage of it. Chronography developed scientific methods to measure past time within specific sets of questions, it was writing about time, not stories.

In this context one can take a closer look at Michael's chronicle, a "look" in the literal sense of the word, for the chronicle not only consists of "text" but also of graphical elements. These graphical and language elements are the specific formal structures of the work. An interpretation of the formal structures seems to be useful, and indeed vital for evaluations of the chronicle. But there are good reasons to believe that the disposition represented by Chabot's facsimile and the Aleppo version respectively is not congruent with the original version. Still there seems to be no doubt as to the "originality" of the chronicle as a synthesis of different historical genres of its tradition, a synthesis which needed both high calligraphic skills, and a strong cognitive drive growing out of a still lively scientific tradition. Some reflections on the function of the formal structures are presented.

\section{HISTORIOGRAPHY}

[1] What is the object of historiography? ${ }^{1}$ Historiography deals with the past, one might say. This definition, however, leads historians into intricate epistemological problems, for "the past" is not a scientific object like any other. In fact, a number of historians have been experimenting with definitions and redefinitions of the object of historiography. They have tried to determine the various relations between "historiography," as a technique to write down a

1 The present contribution is based on a paper given at the symposium on Mor Michael the Great in Damascus, 1-8 October 1999. I would like to thank H.H. Mor Ignatius Zakka I and H.E. Mor Gregorius Yohanna Ibrahim for the honour of their friendly welcome and all the participants of the conference for inspiring talks and discussions.

I would also like to thank the reviewer from the editorial board of Hugoye for revising the language and for improvement of the Syriac passages and the translations. 
record of an analysis of events, ${ }^{2}$ and "history," as a cultural construction based on a variety of elements only one of which is historiography, and finally "the past," which might be defined as everything that ever happened.

In contrast to the modern understanding of the term "historiography" writing of "bistoriae" in the Latin and Greek term often meant writing mainly about the present, about the recent past, or about limited subjects. Writers of "bistoriae" analysed clearly defined events or diachronic developments conceived as "important," and integrated these into specific historical conceptions, which could be universal at times, but they did not deal with "the past." 3 Some ancient and medieval writing of "bistoria" seems to be comparable to a definition by an influential French historian, Marc Bloch, who explicitly disputed the conception of historiography as a science about the past. In his essay "Apologie pour l'bistoire ou métier d'bistorien" he stated:

Car d'abord, l'idée même que le passé, en tant que tel, puisse être objet de science est absurde. Des phénomènes qui n'ont d'autre caractère commun que de ne pas avoir été nos contemporains, comment sans décantage préalable en ferait-on la matière d'une connaissance rationelle? ${ }^{4}$

Bloch argued among others that historiography does not deal with "the past" but with mankind, with unique, living, and dying people, their creations, their social relations and structures. ${ }^{5}$

Bloch's work was shaped by his deep humanity, and so was his actualisation of the already ancient demand on the historian to step out of the library, and to take notice of everything done by people

2 This is the most literal sense of the word, see Herodot, Historiae, Proem, 1. (H.B. Rosén (ed.), Herodoti Historiae, I-II (Leipzig/Stuttgart, 1987-97)).

3 See Herodot, Historiae; G.P. Landmann (ed. and trs.), Thukydides, Geschichte des Peloponnesischen Krieges, I-II (Darmstadt, 1993); F. Paschoudl (ed.), Zosime, Histoire Nouvelle, I-V (Paris, 1971-89); G. Waitz, L. Bethmann (eds.), Paulus Diaconus, Historia Langobadorum (MGH SRG 48; 1887/1978); H. Hagemayer (ed.), Fulcherius Carnotensis, Historia Hierosolymitana (Heidelberg, 1913).

4 M. Bloch, Apologie pour l'histoire on métier d'historien (Cahiers des Annales 3; Paris, 1967) 2.

${ }^{5}$ Ibid., 4. 
in order to gain a deeper understanding of the world we are living in. ${ }^{6}$ And it is also true that Bloch sympathised with the ancient "bistoria" as the most useful term for his own conception. ${ }^{7}$ But is historiography exactly the same as anthropological analysis including a diachronical perspective?

It is true, historiographical methods have improved a great deal, but it also seems to be useful to question our assumptions and categories about this peculiar occupation. For historians usually prefer to look at the diverse and multicoloured world of historical phenomena instead of looking at themselves. This could be one of the reasons for the fact that systematic thoughts about the nature of historiography have largely been developed by disciplines other than historiography: ${ }^{8}$ Historians are being informed that historiography is a narrative. By way of narration the historiographer is said to introduce order into and fabricate meaning about the contingent flow of life. Historiography seen from this perspective is closely connected to or even identical with poetical literature, and rhetoric, it is the production of a story, a story like any other story. ${ }^{9}$ Poetical categories, but usually within a modernist rather than a postmodernist perspective are also used, when medieval historiography is analysed by literary critique.

Many historians, again like Marc Bloch, would not deny the artistic aspects of their science. At the same time the postmodernist conception of narrativity as a fabrication of order and meaning

6 See Chap. VI "Comprendre le présent par le passé," Chap. VII "Comprendre le passé par le présent," Bloch, Apologie, 11-6. Against this optimism see E. Domanska, "Universal History and Postmodernism," Storia della Storiografia 35 (1999): 129-39.

${ }^{7}$ Bloch, Apologie, 15.

${ }^{8}$ For the slow reception of postmodern theory among professional historians see the recent critical article by P. Zagorin, "History, the Referent, and Narrativity: Reflections on Postmodernisms Now," History and Theory 38,1 (1999): 1-24.

9 See S. Hook (ed.), Philosophy and History. A Symposium, (New York, 1963); W.J.T. Mitchell (ed.), On Narrative (Chicago, 1981). As an example for this conception within professional historiography see A. Munslow, Deconstructing History (London/New York, 1997), see also reactions like J. Stückrath, J. Zbinden (eds.), Metageschichte: Hayden White and Paul Ricoeur, dargestellte Wirklichkeit in der europäischen Kultur im Kontext von Husserl, Weber, Auerbach und Gombrich (Baden-Baden, 1997); D. Carr, Time, Narrative, and History (Bloomington, 1993). 
collides with a certain positivistic attitude inherent to historiography. Historians strive to state something, which is "true," or, more precise, something, which is accurate. The production of meaning does not seem to be wholly congruent with the production of a set of accurate statements, relative, subjective, and unsure though they might be. As the analysis is not as yet brought to a close some additional questions remain unanswered: It is obvious that modern historiography does not always read like narrative literature, and that it deliberately developed well defined forms of historical language not even designed to be narrations. ${ }^{10}$ It is also true that historians in general are not very innovative in their usage of language nor genre. Many an ancient or medieval work of historiography does not read like poetical literature either. Here again the usage of language and genre usually is simple and traditionalistic rather than creative, and often also deliberately so. ${ }^{11}$ However, the "deconstructionistical challenge" is not to be refuted by these hardly controversial observations, for the representatives of the conception of narrativity have their theoretical reasons to ignore these differences. ${ }^{12}$

In fact, the present paper does not intend to refute this conception, for it has proved to be a very useful device for the analysis of historiography in many of its aspects. ${ }^{13}$ Instead the reflections shall be confined to discuss the assumption that historiography which does not read like a fluent narrative is historiography in its infancy or mediocre historiography.

${ }^{10}$ P. Lehy (ed.), Droysen, Johann G., Historik. Historisch-kritische Ausgabe, I (Stuttgart: Bad Canstatt, 1977) 445-50: "Die Topik." In this passage Droysen (1808-84) describes the following forms of historical language: "untersuchende Darstellung," "erzählende Darstellung"—in its filiations of "pragmatische," "monographische," biographische," katastrophische"- "didaktische Darstellung," and "diskursive Darstellung." See also J. Kocka, "Zurück zur Erzählung? Plädoyer für historische Argumentation," in idem, Geschichte und Aufklärung, Aufsätze (Göttingen, 1989) 8-20.

11 See the collection of prefaces e.g. by E. Riad, Studies in the Syriac preface (Uppsala, 1988). Statements about the intended language are not necessarily wholly topical as a means for the captatio benevolentiae, for the language indeed is a specific one.

12 Against Zagorin, "History, the Referent, and Narrativity."

13 See J. Straub (ed.), Eræä̈lung, Identität und historisches Bewußtsein: Die psychologische Konstruktion von Zeit und Geschichte (Erinnerung, Geschichte, Identität I; Frankfurt a. M., 1998). 


\section{CHRONOGRAPHY}

A “chronicle" by early modern, modern and postmodern definition is a text in which material from the past is compiled and brought into a sequential order. The material is said to have been arbitrarily collected, with no sense for meaning. This is widely seen as a deficiency, and it seemed to allow for wide ranging assumptions on the intellectual abilities of the authors, or the cultural mentality they shared. ${ }^{14}$ This reputation has been under question for quite some time; there are some advocates, who argue that this definition is an anachronism as long as medieval chronicles are concerned, and who have shown that even some extremely meagre chronicles do have their own ways of producing historical meaning, hence, of narrative. ${ }^{15}$

This approach led to many new insights into medieval chronicles; methods of production have been successfully investigated, etc. The assumption seems to be correct that some tropic devices are almost always in use; perhaps they are inherent to this genre as well. In the present paper, however, I should like to turn the argument upside down. One could also maintain that many chronicles are not narratives. And this could be a virtue, not a vice. For the debate just sketched it could be of interest to know more precisely, which devices other than narrative are used in historical texts.

The most important clues for the analysis could be the very features of the chronicles which led to the replacement of the genre

${ }^{14}$ A. Wirth, Aus orientalischen Chroniken (Frankfurt a. M., 1894) III-IV; K. Krumbacher, Geschichte der byzantinischen Literatur. Von Justinian bis zum Ende des Oströmischen Reiches (527-1453) (München, 1897) 220. More recent: H. White, "The Value of Narrativity in the Representation of Reality," in W.J.T. Mitchell (ed.), On Narrative (Chicago, 1981) 2-23.

15 This field is currently expanding very rapidly. As an early example I would like to mention R. Schmidt, "Aetates mundi. Die Weltalter als Gliederungsprinzip der Geschichte," Zeitschrift für Kirchengeschichte 67 (1956): 288-317. A meagre chronicle in Hebrew has been reinterpreted by Gerson Cohen, comp. his edition and translation of the Book of Tradition (Sefer ha-Qabbalab) by Abraham ibn Daud (Philadelphia, 1969); meagre chronicles have also been investigated by A. Palmer, with contributions by Sebastian Brock and Robert Hoyland, The Seventh Century in the West Syrian Chronicles (Liverpool, 1993). 
in western historiography: ${ }^{16}$ Medieval chroniclers seem to have been less interested in understanding mankind in an anthropological manner. Instead, the chronicle seems to have been a historical genre which was occupied with past events as such, and what could be known of them. A medieval scholar situated in Paris, Jarrow, Melitene or Edessa cannot be expected to make use of Babylonian, Hellenistic or Roman archives. But he also collected data according to his purpose, and his abilities.

As has been said, this occupation did not necessarily lead to the production of a narrative nor even to fluency of speech. But there seems to be a crucial misconception. Writers of Europe and the Middle East in fact shared not only the same early Christian tradition but also the same terminology: Isidore of Seville (+636) explains the term "Chronica" like this: "Chronica Graece dicitur quae Latine temporum series appellatur, qualem apud Graecos Eusebius Caesariensis episcopus edidit, et Hieronymus presbyter in Latinam linguam convertit. XHPONO $\Sigma$ enim Graece, Latine tempus interpretatur." 17 Bede the Venerable (+735) composed a work called "De temporum ratione" /about the calculation of times."18 And likewise we find the term "books about the calculation of the years." 19

The consequence of these well known facts is at the same time obvious and baffling. The chronicler was neither a writer of stories, nor of "historiae." For he was a writer of time. Hence, he produced time-writing, descriptions of times, chronographia, maktbônût zabnê. "Time" was an intricate problem of theology, for theologians discovered that time itself was not an eternal, but itself a historical phenomenon, that is to say, a phenomenon which was once brought into being and which would perish like everything else. Consequently Augustine of Hippo $(+430)$ started to question God and himself about the nature of time. What is time? And how could future, present and past be? None of these are, for time is either not

${ }^{16}$ For the transition from medieval to modern historiography see U. Muhlack, Geschichtswissenschaft im Humanismus und in der Aufklärung. Die Vorgeschichte des Historismus (München, 1991).

${ }^{17}$ Isidor, Etymologiae, V, 28 (W.M. Lindsay (ed.), Isidori Hispalensis Episcopi Etymologiarum sive originum Libri XX (Oxford, 1911).

18 Th. Mommsen (ed.), "Bedae Chronica maiora ad a. 725 eiusdem Chronica minora," in MGAA 13 (1898): 247-327.

${ }^{19}$ Michael, Chronicle, 377 (II, 357). 
yet or not any more. ${ }^{20}$ Time was also a problem of mathematics. Chronography is related to both these disciplines, ${ }^{21}$ which are both designed to produce order and meaning, but which are not poetry. Analytical tools become blunt when they are used indiscriminately. And as little as one would describe mathematics and theology as infant stages of rhetoric and poetry, one should view chronography as a premature stage of rhetorical historiography.

[12] The main occupation of the chronicler was the measuring of "the past," something Augustine in fact thought to be impossible, for it obviously did not exist. Time, Augustine said, could only be measured as it was lived through: "Cum ergo praeterit tempus, sentiri et metiri potest, cum autem praeterierit, quoniam non 'est', non potest. / As time is passing by, it is possible to sense and to measure it, when it is passed, however, it is not possible, because it is not." 22 The impossible came into being by a scientific trick invented before the days of Augustine: ${ }^{23}$ The chronographers measured memories. Memories contained time, lived through, and therefore existent, by others. And hence, an intersubjectively intelligible conception of time was brought into being. Time might have been created by God, this is not for the historian to decide. "Time" in the way we conceive it, was also created by man, it is a cultural construction.

Different notions and aspects of historical writing can therefore be perceived: Ancient historiographers of contemporary history wrote down an analysis of a certain human problem and integrated their results into their specific conception of time, without seeing neither the need nor the possibility to prove their

20 Augustine, Confessiones XI, 14. (M. Skutella et al. (eds.), S. Aureli Augustini confessionum libri XIII (Stuttgart, 1996).

21 The position of historiography and chronography within the medieval systems of science still needs further comparative research. But it seems to be methodologically adequate to use with all due reservations some results about the Latin West, like H.-W. Goetz, "Die Geschichte im Wissenschaftssystem des Mittelalters," in F.J. Schmale, Funktion und Formen mittelalterlicher Geschichtsschreibung (Darmstadt, 1987) 164-213.

22 Augustine, Confessiones XI, 16.

23 The reasons for the invention have been analysed and need not be discussed in the present paper, see A.-D. von den Brincken, Studien zur lateinischen Weltchronistik bis in das Zeitalter Ottos von Freising (Düsseldorf, 1957); A. Momigliano, The Conflict Between Paganism and Christianity in the Fourth Century (Oxford, 1963), A.A. Mosshammer, The Chronicle of Eusebius and Greek Chronographic Tradition (Lewisburg/London, 1979). 
particular conception with 'hard data' about "the past" in general. Modern professional historians also make use of ready made conceptions of time, unlike their ancient predecessors they can now move several millenniums backwards and forwards within them to integrate their records. Pre-existing conceptions of time have become traditional, then naturalised; they are now seemingly self-evident.

[14] But once they were not. And chronography was thinking about time, a pragmatic process of inventing models, of finding abstract symbols and signs to record the measurement of memories and thereby of creating or reworking the conception of time itself. This was done within a theological framework of thoughts about the nature of timeliness, eternity, createdness, and the Creator. The result would be universal chronography, a world chronicle, like the chronicle by Michael the Great.

\section{SOME FORMAL STRUCTURES IN MICHAEL'S CHRONICLE}

[15] Before we are sufficiently prepared to invite the venerable patriarch to take part in our discussion, one additional methodological problem should be mentioned. Is it possible to analyse Michael's chronicle without knowing all its sources? Certainly it would be a great advantage to know them. Does there exist anything within it apart from its sources? ${ }^{24}$ And if not, is the present work identical with them? Since it has been proven elsewhere that in fact Michael's chronicle is not identical with its known sources, ${ }^{25}$ the question is answered adequately for the present purpose. If it is not identical, what is the difference between the chronicle and the sources? And why did the Syriac chroniclers who shared the same sources make not exactly the same use of them? There are differences of size, wordings, forms of language, forms of

${ }^{24}$ See the methodological approach by H. Teule, "The Crusaders in Barhebraeus' Syriac and Arabic Secular Chronicles: A Different Approach," in K. Ciggaar, A. Davids, H. Teule (eds.), East and West in the Crusader States: Context_Contacts-Confrontations (Orientalia Lovaniensia Analecta 75; Louvain, 1996) 39-49.

25 For example by J. van Ginkel, John of Ephesus. A Monophysite Historian in Sixth-Century Byzantium (Groningen, 1995); idem, "Making History: Michael the Syrian and His Sixth-Century Sources," in Symposium Syriacum VII (Orientalia Christiana Analecta 256; Rome, 1998) 351-8. 
representation. These features are specific formal structures, some of which shall be the object of the present reflections. How did these differences occur? One of the methodological preconditions of the present paper is the assumption that they did not occur haphazardly but because different authors had different purposes about which the analysis of the entire work rather than of the sources will produce the decisive clues.

[16] After leafing through the book for a while the most prominent feature becomes evident: Aesthetic devices are being used, text is arranged in certain patterns. Usually three columns of text material are to be seen, containing different aspects of earthly life: the churches, the states, and some mixture of material not easily defined in the third. This system is further enlarged with charts of figures. These charts show the synchronisation of different calculations of time. In addition to this, the flow of the texts and of the times is frequently interrupted by headings, headings of chapters, and headings of books respectively, which produce succeeding portions. Hence different systematic, chronological, and mathematical structures are being blend on the page of the book, the text is a texture as it were, a tapestry like organisation of words, figures, and lines.

Such devices at work allow only one conclusion: In Michael's chronography everything matters, not only the letters of the text. The letters can be read, transformed into a new medium, translated into Arabic or French. But something is lost along the way, the features in Michael's chronicle, which only can be looked at. While some of the sources for this disposition shall be discussed later on it shall be stressed here that no direct predecessor can be traced. It seems to have been an original invention.

This also seems to have been the impression of the first European editor of the chronicle. When abbé Jean-Baptiste Chabot ordered a copy of the manuscript of Michael's chronicle in Edessa in 1897 he explicitly asked for a documentary copy, which would conserve all important optical features. Chabot reports that a youngster, whom he calls Abdallah, was appointed to supervise this difficult and unusual procedure. ${ }^{26}$ And Chabot justified his surprising decision to publish Michael's chronicle not as a transcription. He stated, that "il nous a paru fort utile pour ne pas dire

${ }^{26}$ J.-B. Chabot, Mes chroniques (Paris, 1947). 
indispensable, de garder cette disposition du texte dans notre édition." ${ }^{27}$ His edition therefore is an exceptional case of editorial prudence.

Chabot for obvious reasons never had the opportunity to see the Edessene version again, ${ }^{28}$ and consequently was not able ever to evaluate the quality of his copy. He also must have been aware of the fact that Abdallah cannot have taken his task very seriously, for there are no glosses by a second hand. After the comparison between the layout of Chabot's edition and of the microfilm of the Edessene Manuscript Chabot's assumption can be confirmed: Chabot's copy is indeed documentary insofar as it imitates the disposition correctly, apart from some minor mistakes. But is the disposition of this copy original? In his introduction Chabot led the reader to believe that the layout of his copy resembled the autograph; hard proof, however, he had none. ${ }^{29}$

There are strong reasons for doubt: Editorial and codicological experience has shown that chronicles with aesthetic features can become distorted and even utterly incomprehensible through the copying process. ${ }^{30}$ Medieval and early modern scribes in Europe did not produce documentary copies, each manuscript is unique in its layout. However improbable by analogical comparison, it is true that this kind of evidence has not as yet been produced for chronicles in Syriac. There still might be the slight possibility that Syriac scribes of chronicles followed a different practice. To study their customs one would like to compare different versions, but

${ }^{27}$ Idem, "La chronique de Michel le Syrien. Note de M. l'Abbé J.-B. Chabot," in Académie des Inscriptions et Belles-Lettres. Comptes rendues des Séances, 476-48, here: 483.

${ }^{28}$ Thanks to hints by $\mathrm{H}$. Kaufhold I was able to allude to the painful circumstances of Chabot's acquisition in "The World Chronicle by Patriarch Michael the Great (1126-1199): Some reflections," Journal of Assyrian Academic Studies 11 (1997): 6-29, here: 9-10. Some further details will be mentioned in the forthcoming publication of my doctoral thesis.

${ }^{29}$ J.-B. Chabot, "Introduction," in idem (ed.), Chronique de Michel le Syrien. Patriarche Jacobite d'Antioch (1166-1199), I-IV (Paris, 1899-1924) I, i-lx, here: xli.

30 See e.g. R. Helm, Eusebius' Chronik und ihre Tabellenform (Berlin, 1924); A.-D. von den Brincken, "In una pagina ponendo pontifices, in alia pagina imperatores. Das Kopieren der tabellarischen Papst-KaiserChronik des Martin von Troppau OP (+1287)," Revue d'bistoire des textes 18 (1988): 109-36. 
alas, this method is of no use for the analysis of a historical tradition, where almost every work is preserved only in one copy.

The only way to determine the relation between the original and the only extant copy is a study of the copy itself: the Edessene manuscript, now preserved in St. George in Aleppo. Although it is possible to work with Chabot's edition the differences between the copy by Michael bar Barsaumô of 1598 and Chabot's copy should be stressed. ${ }^{31}$ With Chabot's edition in view it is very difficult to imagine that Michael's chronicle could once have been a beautiful work of chronographical art. The Aleppo manuscript on the other hand was executed with care, the hand is good and regular, colours were used, calligraphic effort is to be seen. The scribe's care reflects his own aesthetic aims. One feature of his personal style obviously was his liking for symmetry and evenness of the disposition, which has been blurred by the modern hand. This personal taste causes a lot of problems for the reader of his version, as we shall see.

His care rather than his style, however, might be a shadow of the original: Patriarch Michael himself took great interest in writing and in calligraphy. A reproduction of the Aleppo manuscript therefore seems to be the best solution in view of any decision about a possible new edition of the text. A close study of this manuscript, search for clues for possible distortions, for remarks of the author, and the scribes might offer insights into the original disposition: There can be no doubt that without the precise determination of the relation between the copy and the autograph evaluations of the chronicle seem to be premature. Any assumption about the clarity of Michael's historical vision-depends on our ability to see.

The data already established can be grouped as follows: Firstly, several oddities in the text and in the layout together with complaints of the scribes about the bad condition of the manuscript they were copying, e.g. about fragmented folios, corroborate the hypothesis formed on methodological grounds. The present state is indeed not the original disposition. The second group of oddities and comments by the scribes indicate some features of the original.

31 See Chabot, "Introduction," on all matters of transmission and the providence of the manuscript. 
[24] In the present paper a detailed description of these data is not possible, ${ }^{32}$ a few examples shall suffice: Chabot states in his introduction that the columns were arranged from right to left as church, state, and mixed column. This description is inaccurate, as he himself must have known. The church history is always placed in the outer column, that is to say, it forms the right column on the right page and the left column on the left page. Accordingly the mixed column is always placed in the inner margin. This disposition collides with the description of the original preserved by the first scribe, who had the autograph at his disposal. Moses of Mardin's description does only allow the assumption of a congruent instead of a symmetrical disposition: 33

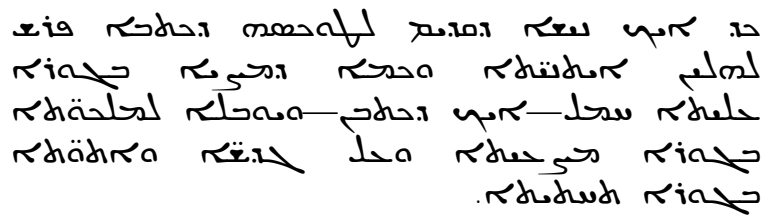

It must have been Michael bar Barșaumô, the second scribe, who distorted this feature of his model. He explicitly regretted his decision after a while, and formed the resolution to change his arrangement from now on, as he tells us: ${ }^{34}$

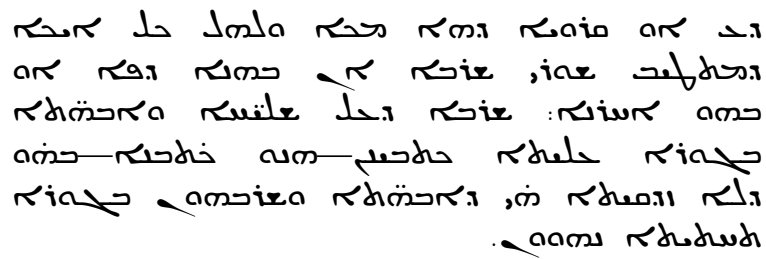

Whether or not a chapter starts on the right or on the left page he always resolves to write the beginning of the church history on the right side "for it is not suitable for the fathers and their deeds to be in the inferior column."

This intention leads to much further trouble, for the scribe starts to confuse his columns now as he noticed himself. ${ }^{35}$ The symmetry therefore was his invention, and it was one, as he

\footnotetext{
32 See the forthcoming edition of my doctoral dissertation.

${ }_{33}$ Michael, Chronicle, 377 (II, 356-7).

34 Ibid., 98 (I, 161).

35 Ibid., 112 (I, 188); 114 (I, 192), 338; 323 (II, 269).
} 
discerned himself, which blurred a specific function of patriarch Michael's tukôsô. In the original there apparently was a hierarchical order which underlined the importance of the deeds of the fathers and expressed the veneration for them. Moreover a decreasing 'importance' of historical notes from right to left can be suspected. Compared to the content of the columns this observation seems to make sense.

[26] Moses also tells us that the patriarch not always used the threecolumn-system. He states that Michael used a one-column layout for more detailed chapters - be it church or secular history-and that he, Moses, imitated it closely: 36

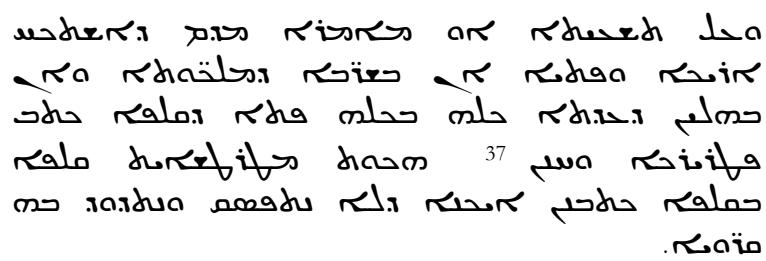

A one-column layout is nowhere to be seen in the Aleppo manuscript. But its original place might be suspected: The books VII to XI contain a lot of detailed material. Here linear text can be found written in three columns. Additionally, a two-column layout occurs, which is again used for book XIV. This mimrô consists of a systematic treatise about the origins and the history of the Turks in several chapters. In the present manuscript these chapters are arranged side by side; the reader is compelled to leaf forwards and backwards to read them in their proper order; the original numeration has been skipped.

One consequence of the scribe's unauthorised artistic ambitions is probably most strongly felt by readers who only deal with the Syriac version: In contrast to patriarch Michael's and the scribe Moses' intentions just quoted, the reader is time and again confused by changes in the arrangement of the columns; he never knows where to continue his reading after reaching the bottom of a page.

[28] But the first scribe must have changed the chronicle as well. At the end of the comment quoted above he tells us that for reasons of explaining method and sources "[...] sôm hwô l-hônô skốlyôn haw

\footnotetext{
${ }^{36}$ Michael, Chronicle, 377 (II, 356).

${ }^{37}$ Emendation by Chabot.
} 
pateryarkôo mnôhô d-Môr Mîkồil." 38 That is to say, the patriarch once placed a comment on this page, but what we see today is a text by the scribe, who, for unknown reasons, only paraphrased the author's gloss. He might have abbreviated it, as he probably also did with another gloss, which shall be discussed in greater detail later on. ${ }^{39}$

In both cases the patriarch himself was originally elucidating the principles of his arrangement. The first one mentioned must have been a recapitulation of the exposition, probably in form of a proem (i.e. the nîshố da-qdìm l-tukôseh da-ktôbổ), which was lost already when Moses was copying the book. Moses understood that the patriarch had reasons to recapitulate some points. He also gives the patriarch's reasons for the three-column-system: To achieve the utmost clarity possible_ as Michael tells us through Moses-his task was d-kad kmô d-masyô takes w-paresh w-awsep bû Môr Mîkổil "as far as possible Môr Michael organised, and separated, and supplemented his material." He reworked the entire corpus of his sources, synchronically and diachronically, as he compared and interwove earlier and later sources at his disposal.

But why did Moses not copy the entire text? What could he possibly gain from paraphrasing these glosses? He might not have wanted to lay open explanations for those features of the disposition he did not imitate.

There are some more features, which must have been distorted by the copying process, maybe by Moses: The chronological canon obviously is badly damaged as was already noticed by the second scribe, who complained about its corruption with increasing indignation. ${ }^{40} \mathrm{He}$ also asked the right question. Who, the first scribe or the author, is responsible for the confusion? ${ }^{41}$ The trouble already starts in the very beginning of the canon, on page 18 in the Syriac version. Instead of writing down one figure after the other per line and column, someone hoped to facilitate his task. The once identical columns of the kûnôshô da-shnayô and of the years of the Hebrews e.g., both starting with number ' $a$ ' are out of order after only seven lines in Chabot's copy. Although it cannot be ruled out that some of the mistakes in the calculation date back

\footnotetext{
38 Michael, Chronicle, 377 (II, 356-7).

${ }^{39}$ Michael, Chronicle, 450 (II, 483). See further down in this paper.

40 Ibid., 74; 110 (I, 237); 112 (I, 237); 117 (I, 238); 255 (II, 533, nr. 7).

${ }^{41}$ Ibid., 113 (I, 238).
} 
to the author, mistakes like these are occurring by copying without understanding.

In the present manuscript there is no connection between the canon and the text, which is odd and lends credence to the suspicion that Moses changed the arrangement of canon versus text. Two points in favour of this suspicion shall be mentioned here: First, page 21 and page 32 in the Syriac text do show a connection between the canon and the text. The disposition of these pages cannot be discussed in detail in the present paper. These pages apparently have been composed out of fragments of folios and thus some original features might have been conserved here by chance. Second, as was mentioned above, the chronographer needs both dated memories and mathematics to establish a time scale. By comparing several dated events he achieves synchronisation: $\mathrm{He}$ can now prove that event $\mathrm{X}$ in the year 6 of king $Y$ happened at the same time as event $\mathrm{W}$ in the year 21 of king Z. This method can be observed everywhere in Michael's chronicle, primarily in the headings of the books and in the column describing and counting the kings of the earth.

The canon or the chart is established accordingly: The chronographer would, confronted with the informationthat event $\mathrm{X}$ took place in the year 6 of king $\mathrm{Y}$, count down from 1 to 6 in his chart-for the numbers 1 to 6 are now proven to have been existent-and write down the said event at number 6 . This method is the reason for 'empty spaces' in chronography. If there is no lemma for year 5 or the years 7 to 12 of king $\mathrm{Y}$ the space is left empty, albeit counted down in the charts, provided the chronographer discovered yet another event dated for the year 12 of king Y.

Several aspects I hope to have demonstrated: Events are needed to prove the time scale, not vice versa. Only after the initial time scale is sufficiently established it can in turn be used to date events, now by comparisons like "event B must have happened before event X which happened in the year 6 of king Y." Secondly, this process is very complicated. To arrange the record of the analysis on a sheet of parchment or paper preliminary experiments and high calligraphic skills are acquired. ${ }^{42}$ Thirdly, a disposition which shows no connection between the calculation and the events

${ }^{42}$ See Mosshammer, The Chronicle of Eusebius, 66. 
necessarily requires a pre-existing chronological system, which already provides the complete structure of the time scale.

For Michael there was no such a system. He himself calculated the chronology from the $8^{\text {th }}$ to the $12^{\text {th }}$ century as we shall see. For these parts at least the canon must have been connected with the memories. It becomes clearer now, why Michael would change to a one-column system to write down some detailed narratives: In these parts, certainly in the books VII to IX, the calculation was interrupted, narrative parts were inserted, and the canon taken up again afterwards. And last but not least: Any chronological canon is difficult to copy, but this is even more the case with an intricate system like the one by patriarch Michael.

How exactly Michael's disposition must have looked like certainly needs further examination and discussion of the data presented here. Two further clues shall be mentioned: On page 21 the (upright) canon is identified with a heading in a larger script as the "menyônô da-shnayô." Page 21 also shows a second heading above the left column: "yûbôl kôhnề" / "the succession of the highpriests." These headings could be a relic of the original disposition; in the present system they are redundant.

Until page 88 the side columns show approximately half the width of the middle column, the script is likewise half sized. This feature provoked a far reaching interpretation by Andrew Palmer, who assumed that "the natural disasters [...] and the church history [...] appeared as 'handmaidens' of secular history." 43 This assertion collides with the prominent place given to priesthood in Michael's chronicle. Through the discussion of several sources, the most prominent being the Ecclesiastical Hierarchy by Dionysios the Areopagite and the treatise on priesthood by John of Dara, Michael leaves no doubt that priesthood exists as a gift from heaven. ${ }^{44}$ The kings of the earth on the other hand are established by manhood, they are part of people's drive for power, and violence. ${ }^{45}$ Unlike priesthood, the kingdoms are wholly part of the historical, the transitory world, of ôlmô óburro. ${ }^{46}$ Hence, the reason for the uneven

43 Palmer, The Seventh Century in the West Syrian Chronicles, 86.

44 Michael, Chronicle, 1-17 (I, 3-32).

45 Ibid.

46 See the heading of Appendix I, which originally must have been serving as an index to the chronicle, Michael, Chronicle, 741ff. These 
layout until page 87 must be a different one. Maybe the middle column expanded at the expense of something originally arranged there as a fourth column, i.e., the canon?

The prime model for Michael's arrangement, the chronicle by Jacob of Edessa (+708), is extant only in a fragmentary state of yet again another secondary copy, Ms. London BM Add 14, 685.47 Nevertheless it clearly shows the iconographic elements of the Eusebian chronicle in the Eastern tradition. The chronological canon is placed in the middle of the page, and events are coordinated to it in loose text patterns necessary for the chronographical method. Patriarch Michael addresses those readers who have come across his book in search for knowledge and informs them that he used good and acknowledged sources, especially the chronicle by Jacob, as far as the calculation of time was concerned. 48

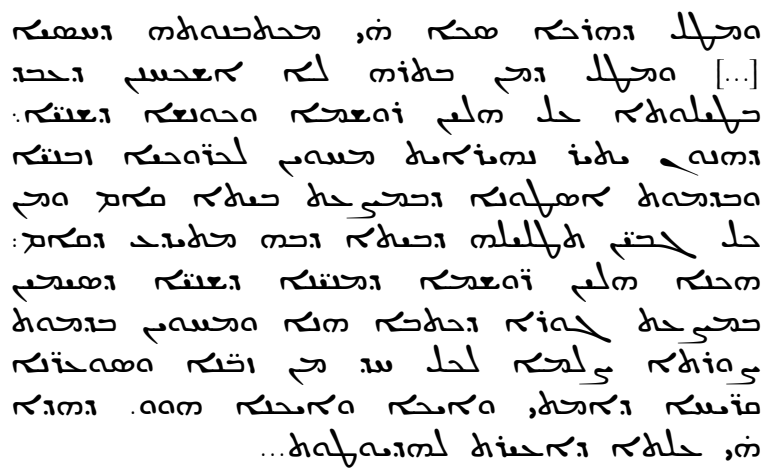

Because here the chronicle of the bishop [...] ends, and because after him we have found nobody who undertook with such diligence a presentation and a summary of years, which could so especially clearly show the temporal cycles, like a pillar standing in the middle of a house, and from all sides supporting the roof of the house, likewise these representations of calculations of years, which are placed in the middle of

headings resemble the headings on page 21 , and therefore corroborate the assumptions mentioned above.

${ }^{47}$ See W. Wright, Catalogue of Syriac Manuscripts in the British Museum, III (London, 1872), 1062-4.

${ }^{48}$ Michael, Chronicle, 450 (II, 483). Emendations by a member of the editorial board. 
the page of this book, and they show like a painting the picture of each time, and the specific events, and when, and where, and how they had been. And this very thing awakened my stupidity.

This passage might be mutilated, and, what is more, at this point Moses might have broken off, as mentioned above. But still it is crucial for the understanding of Michael's chronicle. Michael's style usually is rather sober and shaped by every-day language. Poetical outbursts were not of his liking. His enthusiasm for Jacob must be genuine, and consequently his metaphors must be taken seriously: Jacob's (original) chronographical work triggered artistic associations in Michael's mind, to him it resembled a painting. For one short moment the person Môr Mîkô'îl materializes. We catch a glimpse of a medieval power, a power brought about by the practice of meditation: Just as it may turn a few coloured concentric circles on a parchment into the vibrant vision of the beauty of the Heavenly Jerusalem in the mind of the viewer, ${ }^{49}$ so here it brings abstract structures into blooming life. This passage also informs about the specific reading technique required by a construction like this one: It cannot be read quickly but rather it requires study, meditation, movement of the eyes back and forth, left to right, right to left.

Together with the clues already discussed, this passage provides the basis for the assumption that the metaphor of the upright pillar was the decisive motive for the original shape of Michael's own chronological canon. This reminds us of the fact that the most prominent iconographic elements in copies of Eusebius' evangelical canon, the original model for his chronological canon, are pillars and arches. 50 The same arches_-albeit simplified a great deal-are one iconographic element still preserved in the present version of Jacob's chronography.

49 Representations of the Heavenly Jerusalem in medieval book painting are amazingly abstract, see B. Kühnel, From the Earthly to the Heavenly Jerusalem, Representations of the Holy City in Christian Art of the First Millennium (Rom/Freiburg/Wien, 1987).

50 See J. Leroy, Les manuscrits syriaques à peintures, conservés dans les bibliothèques d'Europe et d'Orient. Contribution à l'étude de l'iconographie des églises de langue syriaque, I-II (Paris, 1964); C. Nordenfalk, Die spätantiken Kanontafeln. Kunstgeschichtliche Studien über die eusebianische Evangelienkonkordanz in den ersten vier Jahrbunderten ibrer Geschichte (Göteborg, 1938). 
There are many more points to reflect concerning the Occidental and the Oriental tradition of Eusebian canons in theological, and historico-theological literature. In the present paper the main problem, however, is the function of the features. For Michael the function of Jacob's - and most probably of his own - system was a methodological one: How to visualise when, and where, and how everything happened.

[41] At this point some important differences between traditional chronography and Michael's work already alluded to come to mind. As soon as one takes Michael's work into one's hand one will discern a feature, which is banal to mention only on first sight: It is rather voluminous. Michael's chronicle is not of the type of meagre chronography but one which is particularly concerned with the concrete content of the 'ubdônê (memoriae) alongside with the time they preserved. To show and to reflect this content, the su rône or the sarbê (gesta), and the taśsyotô (bistoriae) must have been one of the author's purposes.

The vastness of the work cannot be explained by the abundance of source material at his disposal as becomes evident, when Michael's chronicle is compared to the work by Elia of Nisibis (+1046). Elia shared many of the sources with Michael, but he summarised the same texts a great deal further, because his own intention for establishing a chronography was apparently a different one. His chronography needs analysis of its own right, but since one part of Elia's chronicle deals with the problem of calculating with different chronological systems it may be assumed that Elia, like the Latin author Sigebert of Gembloux (+1112), might have been primarily concerned with the calculation, and the establishment of a good chronology and transparent charts to show it. ${ }^{51}$

${ }^{51}$ Elia's chart has been distorted in the edition, because the editors were interested only in the historical notes: E.W. Brooks, J.-B. Chabot (eds.), Eliae metropolitae Nisibeni opus chronologicum, I-II (CSCO 62-3; SS, 21-4; Paris, 1909-10). L.K. Bethmann (ed.), "Chronica Sigeberti Gemblacensis a. 381-1111," in MGH, SS VI (1844) 300-374. See A.-D. von den Brincken, "Contemporalitas Regnorum. Beobachtung zum Versuch des Sigebert von Gembloux, die Chronik des Hieronymus fortzusetzen," in D. Berg, H.-W. Goetz (eds.), Historiographia Mediaevalis. Studien zur Geschichtsschreibung des Mittelalters, Festscbrift für Franz-Josef Schmale zum 65. Geburtstag (Darmstadt, 1988) 199-211. 
[43] And there is the systematic component, the distinction between church-, world-, and mixed column. Distinctions were made before, but such a clear juxtaposition was indeed new. In the West a somewhat similar structure was developed in the Late Middle Ages, the 'pope-emperor-chronicle', like the one by Martin of Troppau. ${ }^{52}$ Hence, the iconographical elements "chronological canon," and "world chronicle" are not the only features of Michael's chronicle. They are enhanced by additional optical features, the juxtaposition, and by features of language, like the systematic headlines for books and chapters not used in traditional chronography, but in narrative historical genres.

The new character of Michael's chronicle and some other Syriac historical works has been noticed before and it has been explained by influence brought about by profane historical narratives. 53 This explanation causes a number of logical and historical problems. ${ }^{54}$ Why reach out so far, when the solution is close at hand? Prior to Jacob's chronography a universal narrative genre was in use. It seems to have died out in the late $6^{\text {th }}$ century with the work by Cyrus of Batnô: ${ }^{55}$ Adaptations, translations, and continuations of the Eusebian church history.

The church history by Eusebius represented an exegesis of the present since the moment of the incarnation as a process of progress, brought about by one church, acting on and within one world. Five hundred years later there were many churches, and the view of the historical process as a progress of inner worldly salvation collided with the permanent existence of Islam. Islam posed a great challenge to any kind of Christian universal historical

52 See above, van den Brincken, "In una pagina ponendo pontifices, in alia pagina imperatores."

53 W. Witakowski, The Syriac Chronicle of Pseudo-Dionysius of Tel-Mahrê. A Study in the History of Historiography (Uppsala, 1987) 83-89; R. Hoyland, Seeing Islam as Others Saw it: A Survey and Evaluation of Christian, Jewish and Zoroastrian Writings on Early Islam (Princeton, 1997) 408-9.

54 To mention just one: Michael did not use profane historiography, see on all matters of his use of sources Chabot, Introduction, about the genre of sources also Weltecke, World chronicle, 21.

55 See the latest discussion of the material in Ginkel, J.v., John of Ephesus, 46-85. 
thinking. ${ }^{56}$ One could expect a complete drying out of universal historical writing in the Syriac tradition, and it did take place eventually, but not until the greatest efforts were made to adapt the concept to the new situation.

One such adaptation was achieved by the venerable patriarch Dionysius of Tel-Mahrê (+842). He explicitly intended to follow Eusebius' tradition, and to continue the church history by Cyrus of Batnô. ${ }^{57}$ But he split the genre in two, and wrote one part about the church, and a second one about the state. Patriarch Michael made use of church historical as well as of chronographical sources, as did Jacob and Elia. But Michael did not only use both, the features of his chronicle can best be explained as a synthesis out of the two genres. Michael's chronicle, thus, is just as much a church history as it is a world chronography-both aspects have become one. And at the same time one can clearly distinguish the two different genres it has been made of, including the juxtaposition of churches and states he observed in Dionysius' work.

\section{ASPECTS OF A READING}

The venerable patriarch addressed his reader as Rhadudu lefa ar Rive, ${ }^{58}$ the one who loves the truth or cares for accuracy. His discursive historical language, his diligence in quoting his sources, prevents us from declaring expressions like these to be 'topical': They are consistent with his method. Michael cared for hatitûtô, he wanted to know exactly. He also was fascinated by the Eusebian canon pri horiss th rausis

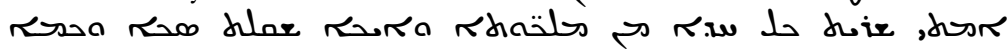

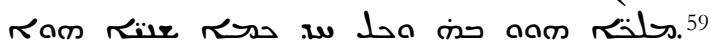

56 See e.g. the forthcoming edition of the papers of Redefining Christian Identity: Christian Cultural Strategies Since the Rise of Islam. Symposium organised by the Universities of Groningen and Leiden, April 7-10 (1999), especially the paper by G. Reinink, on John bar Penkâyê; Palmer, "The Seventh Century," here also S. Brock, "Two Related Apocalyptic Texts Dated AD 691/2," 222-250.

${ }^{57}$ Michael, Chronicle, 378 (II, 358).

58 Ibid., 121 (I, 240).

${ }^{59}$ Ibid., 18. 
Someone who is driven by a strong cognitive drive as Michael was, and who took such great care to visualise his results, has most probably got something to say. And an important though mutilated passage in the beginning of the chronicle also leaves no doubt as to the question that his readers are not only to learn, but are also asked to follow his representation closely from the start in order to understand something. ${ }^{60}$ Indeed many aspects can be understood, that is to say, if the patriarch was asked about his opinion on questions like the importance of priesthood for universal history, the development of the churches, about the nature of man, about God, about the process of civilisation, i.e. script, cities, religion, and science, the reason for catastrophes and death, he seems to have a lot to answer, well grounded on quotations, and "footnotes." Many readings of the chronicle are possible, and the suggestions in the present paper can merely touch the surface. But Michael did not tell a story.

[49] Inherent to narrativation is a process of simplification. We see this process of simplification at work, when Michael's chronicle is compared to the adaptation made by Bar Hebraeus. ${ }^{61}$ When the great scholar used Michael's chronicle for his own purposes, he simplified Michael's representation to one succession of highpriests of Antioch in the first part of his ecclesiastical history, and to one succession of "our own high-priesthood" in the second. In his world chronicle one empire is neatly succeeded by another. This method seems to clarify phases of history, but it is less enlightening, should one try to understand the experience of change of power, and the reasons for that change. Bar Hebraeus might not have been studying this problem, but Michael was.

He reflected upon the existence of war, emphasised the importance of the beginning of earthly rule, and the invention of weapons. ${ }^{62}$ From the very first kings onwards he saw empires competing for land, involved in wars and campaigns of conquest. Not one empire dominates the world in his succession of the kings, but at least two, and the number of earthly powers is further enlarged by the chronological canon and the mixed column. They

${ }^{60}$ Ibid., I (I, 4).

${ }^{61}$ P. Bedjan (ed.), Gregorii Barhebraei Chronicon Syriacum (Paris, 1890); J.B. Abbeloos, Th.J. Lamy (eds.), Gregorii Barbebrei Chronicon Ecclesiaasticum, I-III (Louvain/Paris. 1872-7).

${ }^{62}$ Michael, Chronicle, 2-22 (I, 5-22). 
fight with one another, make peace at some other time, start war again, expand and fade away.

As Michael struggles with the reality of diversity of rule he observes and represents another point very clearly: There usually are no clear-cut successions, states take time to grow and to fade. ${ }^{63}$ Hence, there is not only synchronic diversity of rule, but also diachronic diversity of the changes of rule. Michael's representation, which is not a linear text but uses four dimensions at the same time through graphical devices, suddenly appears to have many advantages. For it is able to bring about a subtly differentiated view of universal change of power.

Through the parallel representations of states and church, and the heresies in the mixed column, the reader is invited to compare these different spheres. The history of the church, or rather, the succession of the high priests, is different in crucial aspects, as mentioned above. But a lot of similarities are too be seen, for Michael was a critical observer. There is a lack of unity within the church as well, there are heresies with their own history, there are ambitious bishops and wilful priests, there is dispute, and sometimes banal quarrel. And these factors again bring about change, and they lead to the existence of a diversity of confessions, each of which Michael tries to show in its specific successions as long as possible. ${ }^{64}$

[53] More than in the "split chronicles" of Dionysius, the anonymous author of the chronicle ad a. 1234, or Bar Hebraeus some additional insights are possible through comparison: Often interrelations between the spheres emerge, direct impact of earthly rule on the succession of the patriarchs and the development of the churches, impact of the rule of the patriarchs on the development of heresies, and so on.

${ }^{63}$ Bar Hebraeus' succession is based on Michael, see Chronicle, 27 (I, 49); 34 (I, 58); 63-64 (I, 101-104); 72f (I, 113); 87f (I, 137), 353 (II, 316), 403 (II, 400), 408f (II, 408f).

${ }^{64}$ Michael, Chronicle, 452-453 (II, 486-7). This passage is not written by Dionysius of Tel-Mahrê but by Michael. It was not of Dionysius' concern. See also e.g. Michael, Chronicle, 239 (II, 122). 
Michael's work cannot be used as a "simple tool for demonstrating God's plan of salvation."65 There are chronicles which are primarily written to this effect. One of the most famous works to mention in this context, and one which cannot justly be called "simple" either, is the "Chronica sive Historia de duabus civitatibus" by Michael's Latin contemporary, bishop Otto of Freising (+1158). ${ }^{66} \mathrm{We}$ also see chroniclers write about the last part of earthly history as if it was part of history already. So did Bede the Venerable, and Otto. Unlike the exceptional thinker Joachim of Fiore (+1202), ${ }^{67}$ however, Augustine, Isidore of Seville, Bede, Otto, and others observed the theological restraint against temptations to any concrete prophecies about the times to come, even if they were sure that the age they lived in would be the last one.

Michael surpasses the Latin writers mentioned in consistently avoiding apocalyptic thinking. He used neither Daniel's prophecy of the ages of the world, ${ }^{68}$ nor the equation of time and the ages of man nor any other apocalyptic narrative figure, which allows to determine the position of the presence within the time system of the transitory world. ${ }^{69} \mathrm{He}$ knew about these figures, of course, but

65 B. Croke, "The Origins of the Christian World Chronicle," in: B. Croke, A.A. Emmet (eds.), History and Historians in Late Antiquity (Sydney/Oxford/New York, 1983) 116-31, here: 127.

${ }^{66}$ W. Lammers (ed.), Otto Bischof von Freising: Chronik oder Die Geschichte der zwei Staaten (Darmstadt, 1960); see H.-W. Goetz, Das Geschichtsbild Ottos von Freising. Ein Beitrag zur historischen Vorstellungswelt und zur Geschichte des 12. Jabrhunderts (Köln/Wien, 1984).

67 Joachim of Fiore, Expositio in Apocalypsim (Venice, 1527, repr. Frankfurt a.M., 1964); idem, Liber de Concordia novi ac veteris testamenti (Venice, 1519); see Atti del Congresso Internazionale di Studi Gioachimiti. Storia e messagio in Gioacchino da Fiore, I-II (Naples, 1980, 1986); M. Reeves, The influence of prophecy in the later Middle Ages. A Study in Joachimism (Notre Dame, 1993).

${ }^{68} \mathrm{Dn} 2,31-44$.

69 See Schmidt, Weltalter; A. Funqenstein, Heilsplan und natürliche Entwicklung. Formen der Gegenwartsbestimmung im Geschichtsdenken des hohen Mittelalters (München, 1965); Schmale, Funktion und Formen, 55ff, A. Angendendt, Geschichte der Religiösität im Mittelalter (Darmstadt, 1997), 213-35 ("Die christliche Zeit"), compare the differences in the interpretation of specific time systems, e.g. like the thinking of Anselm of Havelberg (+1158) — another contemporary of Michael. 
any apocalyptic speculation was inconsistent with his repeatedly emphasised belief that God was almighty, and he told his flock accordingly, when they were shaken by eschatological fear in 1186. ${ }^{70}$ For him contemplation about the future was futile: علد

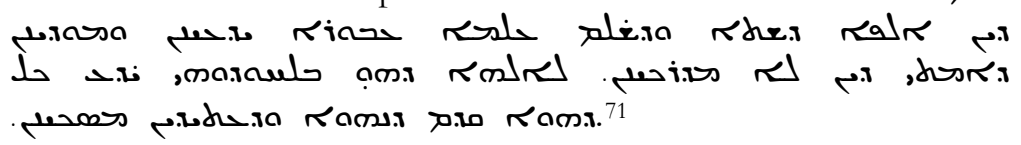

By the process of narrativation, "meaning," that is to say metaphysical "sense," and often teleology is applied to the changing world. But does change have any "meaning"? Michael for one narrativates change far less. To represent historical change without narrativating it too far is one achievement, which could be of importance today, should one try to rethink "time" again. The experience of contingency, of anarchy, of lack of security, is fully acknowledged, hope for the future is trust in God's almighty power, but responsible for change is neither fortuna nor God alone, but man. It was Michael's own experience of a time which was especially anarchical and unpredictable, due to the wars brought about by Frankish knights, Byzantine emperors, Armenian warlords, Turkish governors, and Kurdish nomads. But it is another matter to undergo experiences and to face them with chronographical study. Whereas "winners" in history-as some Latins saw themselves-perceived "history" to be a story of success and themselves its climax, "losers," like some medieval Byzantine chroniclers, closed their eyes and narrowed their horizon. ${ }^{72}$ The great medieval Syriac Orthodox historians, Jacob of

${ }^{70}$ Michael, Chronicle, 731 (III, 399).

${ }^{71}$ Ibid., 264-5 (II, 168).

${ }^{72}$ See e.g. F. Kurze (ed.), Reginonis Abbatis Prumiensis. Chronicon. Cum continuatione Treverensi (MGH SRG 50; 1890); Lammers, Otto Bischof von Freising: Chronik, etc. To see history as a process of progress seems to be so much naturalised in Western historical thinking that the development of this view is usually been described not as a historical and contingent phenomenon but itself as a progress in philosophy of history: It is widely seen as the "discovery" of a "truth." Joachim of Fiore e.g. is welcomed by Robert Lerner, "Joachim von Fiore," TRE 17 (1988): 84-8, here: 88 as "the first European to present a clear concept of progress." See also Funqenstein, Heilsplan. For the shrinking Byzantine horizon and its historical context see C. Mango, "The Tradition of Byzantine Chronography," Proceedings of the International Congress Commemorating the Millenium of Christianity in Rus'-Ukraine, Harvard Ukrainian Studies 12/13 
Edessa, Dionysius of Tel-Mahrê, Michael, the Anonymous, and Bar Hebraeus, were courageous enough to keep their eyes open, and to acquire sources even from those who might be their enemies.

Michael's work came into being by immense research, and through a talent to visualise. But the vastness of his chronicle draws attention to another precondition of his achievement. The venerable patriarch did not turn his back on worldly life but took active notice of it. It had moved him to vigorous action, tireless travels, and negotiations. As Michael started to write more personally in the last parts of his chronicle, compassion and sensitivity become visible, sadness about death through violence and war, sympathy for living beings in pain. ${ }^{73} \mathrm{He}$ for one had stepped out of the library, and taken notice of everything.

\section{QUOTED LITERATURE}

\section{Sources}

Abbeloos, J.B., Th.J. Lamy, eds. Gregorii Barbebrei Chronicon Ecclesiaasticum, I-III. Louvain/Paris 1872-7.

Bedjan, P., ed. Gregorii Barhebraei Cbronicon Syriacum. Paris, 1890.

Bethmann, L.K., ed. "Chronica Sigeberti Gemblacensis a. 381-1111." In MGH, SS VI, 300-374. (1844).

Brooks, E.W., J.-B. Chabot, eds. Eliae metropolitae Nisibeni opus cbronologicum, I-II. CSCO, 62-3; SS, 21-4. Paris, 1909-10.

Chabot, J.-B., ed./trs. Chronique de Michel le Syrien. Patriarche Jacobite d'Antioch (1166-1199), I-IV. Paris 1899-1924.

Cohen, G., ed./trs. The Book of Tradition (Sefer ha-Qabbalah) by Abraham ibn Daud. Philadelphia, 1969.

Hagemayer, H., ed. Fulcherius Carnotensis, Historia Hierosolymitana. Heidelberg, 1913.

Joachim of Fiore, Expositio in Apocalypsim. Venice, 1527, repr. Frankfurt a.M., 1964).

Joachim of Fiore, Liber de Concordia novi ac veteris testamenti. Venice, 1519.

Kurze, F., ed. Reginonis Abbatis Prumiensis. Chronicon. Cum continuatione Treverensi. MGH SRG, 50. 1890.

(1988): 360-71. I expect that one of the outcomes of a systematic comparison between Eastern and Western Christian historical thinking could be a better understanding of the close relation between historical experience and historical theory, and hence, the relativity of the latter.

${ }^{73}$ Michael, Chronicle, 733 (III, 402); 737 (III, 407) etc. 
Lammers, W., ed. Otto Bischof von Freising: Chronik oder Die Geschichte der zwei Staaten. Darmstadt, 1960.

Landmann, G.P., ed./trs. Thukydides, Geschichte des Peloponnesischen Krieges, III. Darmstadt, 1993.

Lindsay, W.M., ed. Isidori Hispalensis Episcopi Etymologiarum sive originum Libri XX. Oxford, 1911.

Mommsen, Th., ed. "Bedae Chronica maiora ad a. 725 eiusdem Chronica minora." MG AA 13 (1898): 247-327.

Paschoudl, F., ed. Zosime, Histoire Nouvelle, I-V. Paris, 1971-89.

Rosén, H.B., ed. Herodoti Historiae, I-II. Leipzig/Stuttgart, 1987-97.

Skutella, M., et al., eds. S. Aureli Augustini confessionum libri XIII. Stuttgart, 1996.

Waitz, G., L. Bethmann, eds. Paulus Diaconus, Historia Langobadorum. MGH SRG, 48. 1887/1978.

\section{Literature}

Angenendt, A. Geschichte der Religiösität im Mittelalter (Darmstadt, 1997).

Atti del Congresso Internazionale di Studi Gioachimiti. Storia e messagio in Gioacchino da Fiore, I-II (Naples, 1980, 1986).

Bloch, M. Apologie pour l'bistoire ou métier d'bistorien (Cahiers des Annales 3; Paris, 1967).

von den Brincken, A.-D. "Contemporalitas Regnorum. Beobachtung zum Versuch des Sigebert von Gembloux, die Chronik des Hieronymus fortzusetzen," in Berg, D., H.-W. Goetz (eds.), Historiographia Mediaevalis. Studien zur Geschichtsschreibung des Mittelalters, Festschrift für Franz-Josef Schmale zum 65. Geburtstag (Darmstadt, 1988) 199-211.

"In una pagina ponendo pontifices, in alia pagina imperatores. Das Kopieren der tabellarischen Papst-Kaiser-Chronik des Martin von Troppau OP (+1287)," Revue d'histoire des textes 18 (1988): 109-136.

- Studien zur lateinischen Weltchronistik bis in das Zeitalter Ottos von Freising (Düsseldorf, 1957).

Brock, S. "Two Related Apocalytpic Texts Dated AD 691/2," in Palmer, A., with contributions by Sebastian Brock and Robert Hoyland, The Seventh Century in the West Syrian Chronicles (Liverpool, 1993) 222-250.

Carr, D. Time, Narrative, and History (Bloomington, 1993).

Chabot, J.-B. "Introduction," in idem (ed.), Chronique de Michel le Syrien. Patriarche Jacobite d'Antioch (1166-1199), I-IV (Paris, 1899-1924) I, i-lx.

-. "La chronique de Michel le Syrien. Note de M. l'Abbé J.-B. Chabot," in Académie des Inscriptions et Belles-Lettres. Comptes rendues des Séances, 476-48. 
Mes chroniques (Paris, 1947).

Croke, B., "The Origins of the Christian World Chronicle," in Croke, B., A.A. Emmet (eds.), History and Historians in Late Antiquity (Sydney/Oxford/New York, 1983) 116-31.

Domanska, E. "Universal History and Postmodernism," Storia della Storiografia 35 (1999): 129-39.

Funqenstein, A. Heilsplan und natürliche Entwicklung. Formen der Gegenwartsbestimmung im Geschichtsdenken des bohen Mittelalters (München, 1965).

van Ginkel, J. "Making History: Michael the Syrian and His Sixth-Century Sources," in Symposium Syriacum VII (Orientalia Christiana Analecta 256; Rome, 1998) 351-8.

- John of Ephesus. A Monophysite Historian in Sixth-Century Byzantium (Groningen, 1995).

Goetz, H.-W. "Die Geschichte im Wissenschaftssystem des Mittelalters," in Schmale, F.J. Funktion und Formen mittelalterlicher Geschichtsschreibung (Darmstadt, 1987) 164-213.

—. Das Geschichtsbild Ottos von Freising. Ein Beitrag zur historischen Vorstellungswelt und zur Geschichte des 12. Jahrbunderts (Köln/Wien. 1984).

Helm, R. Eusebius' Chronik und ibre Tabellenform (Berlin, 1924).

Hook, S. (ed.). Philosophy and History. A Symposium (New York, 1963).

Hoyland, R. Seeing Islam as Others Saw it: A Survey and Evaluation of Christian, Jewish and Zoroastrian Writings on Early Islam (Princeton, 1997) 408-9.

Kocka, J. "Zurück zur Erzählung? Plädoyer für historische Argumentation," in idem, Geschichte und Aufkelärung, Aufsätz̧e (Göttingen, 1989) 8-20.

Krumbacher, K. Geschichte der byzantinischen Literatur. Von Justinian bis zum Ende des Oströmischen Reiches (527-1453) (München, 1897).

Kühnel, B. From the Earthly to the Heavenly Jerusalem, Representations of the Holy City in Christian Art of the First Millennium (Rom/Freiburg/Wien, 1987).

Lehy, P. (ed.). Droysen, Johann G., Historik. Historisch-kritische Ausgabe, I (Stuttgart/Bad Canstatt, 1977).

Lerner, R. "Joachim von Fiore," TRE 17 (1988): 84-8.

Leroy, J., Les manuscrits syriaques à peintures, conservés dans les bibliothèques d'Europe et d'Orient. Contribution à l'étude de l'iconographie des églises de langue syriaque, I-II (Paris 1964).

Mango, C. "The Tradition of Byzantine Chronography," Proceedings of the International Congress Commemorating the Millenium of Christianity in Rus'-Ukraine, Harvard Ukrainian Studies 12/13 (1988): 360-71.

Mitchell, W.J.T. (ed.). On Narrative (Chicago, 1981). 
Momigliano, A., The Conflict Betwen Paganism and Christianity in the Fourth Century (Oxford 1963).

Mosshammer, A. A. The Chronicle of Eusebius and Greek Chronographic Tradition (Lewisburg/London 1979).

Muhlack, U. Geschichtswissenschaft im Humanismus und in der Aufklärung. Die Vorgeschichte des Historismus (München, 1991).

Munslow, A. Deconstructing History (London/New York, 1997).

Nordenfalk, C. Die spätantiken Kanontafeln. Kunstgeschichtliche Studien über die eusebianische Evangelienkonkordanz in den ersten vier Jabrhunderten ihrer Geschichte (Göteborg, 1938).

Palmer, A., with contributions by Sebastian Brock and Robert Hoyland. The Seventh Century in the West Syrian Chronicles (Liverpool, 1993).

Redefining Christian Identity: Christian Cultural Strategies Since the Rise of Islam. Symposium organised by the Universities of Groningen and Leiden, April 7-10 (1999) (forthcoming).

Reeves, M. The influence of prophecy in the later Middle Ages. A Study in Joachimism (Notre Dame, 1993).

Riad, E. Studies in the Syriac preface (Uppsala, 1988).

Schmale, F.J. Funktion und Formen mittelalterlicher Geschichtsschreibung (Darmstadt, 1987).

Schmidt, R. "Aetates mundi. Die Weltalter als Gliederungsprinzip der Geschichte," Zeitschrift für Kirchengeschichte 67 (1956): 288-317.

Straub, J. (ed.). Erzählung, Identität und historisches Bewußtsein: Die psychologische Konstruktion von Zeit und Geschichte (Erinnerung, Geschichte, Identität I; Frankfurt a.M., 1998).

Stückrath, J., J. Zbinden (eds.). Metageschichte: Hayden White and Paul Ricoeur, dargestellte Wirklichkeit in der europäischen Kultur im Kontext von Husserl, Weber, Auerbach und Gombrich (Baden-Baden, 1997).

Teule, H. "The Crusaders in Barhebraeus' Syriac and Arabic Secular Chronicles: A Different Approach," in K. Ciggaar, A. Davids, H. Teule (eds.). East and West in the Crusader States: ContextContacts-Confrontations (Orientalia Lovaniensia Analecta 75; Louvain, 1996) 39-49.

Weltecke, D. "The World Chronicle by Patriarch Michael the Great (1126-1199): Some reflections," Journal of Assyrian Academic Studies 11 (1997): 6-29.

White, H. "The Value of Narrativity in the Representation of Reality," in Mitchell, W.J.T. (ed.), On Narrative (Chicago, 1981) 2-23.

Wirth, A. Aus orientalischen Chroniken (Frankfurt a.M., 1894).

Witakowski, W. The Syriac Chronicle of Pseudo-Dionysius of Tel-Mahrê. A Study in the History of Historiography (Uppsala, 1987).

Wright, W. Catalogue of Syriac Manuscripts in the British Museum, III (London, 1872). 
Zagorin, P. "History, the Referent, and Narrativity: Reflections on Postmodernisms Now," History and Theory 38,1 (1999): 1-24. 
